\title{
TOTAL Escherichia coli PADA SOSIS IKAN YANG DI-COATING DENGAN MIOFIBRIL ASAP CAIR SELAMA PENYIMPANAN
}

\author{
Jupni Keno, Henny A. Dien, Agnes T. Agustin \\ Fakultas Perikanan dan Ilmu Kelautan, Universitas Sam Ratulangi, Manado, Sulawesi Utara.
}

\begin{abstract}
Fish sausages are prepared foods that have a high nutritional value, but that is the weakness of this commodity is rapidly decaying nature. Bacterial pathogens that must be avoided include Escherichia coli. These bacteria are gram-negative, rod-shaped and motile spores are not. The purpose of this study is to calculate the total coliforms and $E$. coli in fish sausage coating of fish protein myofibrils Black Marlin (Makaira indica) during storage at room temperature $\left(28-29^{\circ} \mathrm{C}\right)$, and refrigerator temperature $\left(10-13^{\circ} \mathrm{C}\right)$. The method used is descriptive method, which is a study conducted to analyze an individual, the state, or the symptoms of a particular group. The results showed that the total coliform in fish sausage in coating with liquid smoke is stored at room temperature, the lowest value is $7 \mathrm{MPN} / \mathrm{g}$, the highest of $120 \mathrm{MPN} / \mathrm{g}$, while the lowest value refrigerator temperature is $7 \mathrm{MPN} / \mathrm{g}$, the highest $93 \mathrm{MPN} / \mathrm{g}$. Total coliform in fish sausage in smokeless liquid coating stored at room temperature with the lowest value is $7 \mathrm{MPN} / \mathrm{g}$, the highest $210 \mathrm{MPN} / \mathrm{g}$, while the lowest value refrigerator temperature is $7 \mathrm{MPN} / \mathrm{g}$, and the highest is 120 MPN/g. Total coliform in fish sausages are not in the coating deposited at room temperature with the lowest value is $7 \mathrm{MPN} / \mathrm{g}$, the highest of $240 \mathrm{MPN} / \mathrm{g}$, at refrigerator temperature the lowest value is 7 $\mathrm{MPN} / \mathrm{g}$, and the highest is $150 \mathrm{MPN} / \mathrm{g}$. Total E. coli showed that the fish sausage in coating with liquid smoke is stored at room temperature, the lowest value is $1 \mathrm{MPN} / \mathrm{g}$, and the highest is $4 \mathrm{MPN} / \mathrm{g}$, while the lowest value refrigerator temperature is $<3 \mathrm{MPN} / \mathrm{g}$, and The highest is $3 \mathrm{MPN} / \mathrm{g}$. Total E. coli in fish sausage in smokeless coating liquid stored at room temperature, the lowest value is $2 \mathrm{MPN} / \mathrm{g}$, and the highest is $4 \mathrm{MPN} / \mathrm{g}$, while the temperature of the refrigerator lowest value is $1 \mathrm{MPN} / \mathrm{g}$, and a high of 3 $\mathrm{MPN} / \mathrm{g}$. Total E. coli in sausages are not in the coating deposited at room temperature, the lowest value is $2 \mathrm{MPN} / \mathrm{g}$, and the highest is $5 \mathrm{MPN} / \mathrm{g}$, and the refrigerator temperature is the lowest rating $2 \mathrm{MPN} / \mathrm{g}$, the highest is $4 \mathrm{MPN} / \mathrm{g}$ during storage .
\end{abstract}

Keywords: fish sausage, coating, myofibril, Eschericia coli.

\begin{abstract}
ABSTRAK
Sosis ikan merupakan makanan siap saji yang mempunyai nilai gizi tinggi, namun yang menjadi kelemahan dari komoniti ini adalah sifatnya yang cepat membusuk. Bakteri patogen yang harus dihindari antara lain Escherichia coli. Bakteri ini bersifat gram negatif, berbentuk batang tidak spora dan bersifat motil. Tujuan penelitian ini yaitu untuk menghitung total koliform dan E. coli pada sosis ikan yang dicoating dari miofibril protein ikan Black Marlin (Makaira indica) selama penyimpanan suhu ruang $\left(28-29^{\circ} \mathrm{C}\right)$, dan suhu kulkas $\left(10-13^{\circ} \mathrm{C}\right)$. Metode penelitian yang digunakan adalah metode deskriptif, yaitu suatu penelitian yang dilakukan untuk menganalisa suatu individu, keadaan, gejala atau kelompok tertentu. Hasil penelitian menunjukkan bahwa total koliform pada sosis ikan yang dicoating dengan asap cair disimpan pada suhu ruang, nilai terendah yaitu $7 \mathrm{MPN} / \mathrm{g}$, tertinggi $120 \mathrm{MPN} / \mathrm{g}$, sedangkan pada suhu kulkas nilai yang terendah yaitu $7 \mathrm{MPN} / \mathrm{g}$, tertinggi $93 \mathrm{MPN} / \mathrm{g}$. Total koliform pada sosis ikan yang dicoating tanpa asap cair disimpan pada suhu ruang dengan nilai terendah yaitu $7 \mathrm{MPN} / \mathrm{g}$, tertinggi 210 $\mathrm{MPN} / \mathrm{g}$, sedangkan pada suhu kulkas nilai yang terendah yaitu $7 \mathrm{MPN} / \mathrm{g}$, dan tertinggi $120 \mathrm{MPN} / \mathrm{g}$. Total koliform pada sosis ikan tidak dicoating disimpan pada suhu ruang dengan nilai terendah yaitu $7 \mathrm{MPN} / \mathrm{g}$, tertinggi $240 \mathrm{MPN} / \mathrm{g}$, pada suhu kulkas nilai terendah yaitu $7 \mathrm{MPN} / \mathrm{g}$, dan tertinggi $150 \mathrm{MPN} / \mathrm{g}$. Total E. coli menunjukkan bahwa pada sosis ikan yang dicoating dengan asap cair disimpan pada suhu ruang, yaitu nilai terendah $3 \mathrm{MPN} / \mathrm{g}$, dan tertinggi $4 \mathrm{MPN} / \mathrm{g}$, sedangkan pada suhu kulkas nilai terendah yaitu $<3 \mathrm{MPN} / \mathrm{g}$, dan tertinggi $3 \mathrm{MPN} / \mathrm{g}$. Total E. coli pada sosis ikan yang dicoating tanpa asap cair disimpan pada suhu ruang, yaitu nilai terendah $3 \mathrm{MPN} / \mathrm{g}$, dan tertinggi $4 \mathrm{MPN} / \mathrm{g}$, sedangkan pada suhu kulkas nilai terendah yaitu $<3 \mathrm{MPN} / \mathrm{g}$, dan tertinggi $3 \mathrm{MPN} / \mathrm{g}$. Total E. coli pada sosis tidak dicoating disimpan pada suhu ruang, yaitu nilai terendah $4 \mathrm{MPN} / \mathrm{g}$, dan tertinggi $7 \mathrm{MPN} / \mathrm{g}$, dan pada suhu kulkas yaitu nilai terendah $3 \mathrm{MPN} / \mathrm{g}$, tertinggi $4 \mathrm{MPN} / \mathrm{g}$ selama penyimpanan.
\end{abstract}

Kata kunci: sosis ikan, coating, myofibril, Eschericia coli. 


\section{PENDAHULUAN}

Kesadaran masyarakat mengenai kebersihan pengolahan produk perikanan perlu mendapat perhatian karena dapat menyebabkan penyakit pada manusia. Bakteri penyebab penyakit yang paling umum disebut bakteri patogen antara lain Escherichia coli dan Salmonella sp. Bakteri patogen adalah bakteri yang dapat menyebabkan penyakit yang dapat ditemukan diberbagai tempat, tersebar luas di tanah, air, udara, tanaman, hewan dan manusia. Bakteri tersebut dapat terbawa oleh pangan atau tangan pengolahan dan peralatan masak yang dapat mencemari pangan sehingga menyebabkan penyakit. Umumnya bakteri patogen yang menyebabkan penyakit pada manusia adalah mikroba yang mempunyai pertumbuhan optimal pada suhu $20-40^{\circ} \mathrm{C}$ (Tambani, 1995). Pangan segar terutama daging sapi, unggas, seafood dan sosis ikan yang ditimbulkannya dapat mengandung bakteri patogen yang dapat mencemari bahan pangan seperti di atas selama pengolahan dan penyimpanan. Sebab itu cara agar supaya bahan pangan tersebut tahan lama dan tidak terkontaminasi dengan bakteri perlu digunakan kemasan yang baik.

Edible Coating adalah kemasan yang di buat lapisan tipis dan kontinyu dari bahan yang dapat dimakan. Komponen ini berfungsi sebagai penghambat terhadap transfer massa (misalnya kelembaban, oksigen, lipida, zat terlarut), atau sebagai carrier bahan makanan atau aditif dan untuk meningkatkan penanganan makanan (Krochta, 1992). Bahan dasar dari protein ikan dibuat edible coating (miofibril protein) dan dapat ditambahkan asap cair sebagai pengawet karena bersifat antibakteri dan antioksidan.

Asap cair adalah kondensat dari asap kayu yang telah mengalami penyaringan untuk memisahkan bahan-bahan tertentu. Kondensat asap ini memiliki asap aktivitas fungsional karena mengandung fenol. Menurut Girard (1992), asap cair hasil pembakaran mengandung senyawa kelompok fenol, asam dan karbonil yang ketiganya secara simultan mempunyai aktivitas fungsional sebagai antioksidan, antibakteri dan memberikan cita rasa yang spesifik (Aswar, 1995). Penelitian ini bertujuan untuk menghitung total koliform dan E. coli pada sosis ikan yang dicoating dengan miofibril asap cair selama penyimpanan suhu ruang dan suhu kulkas, menghitung total koliform dan $E$. coli pada sosis yang dicoating tanpa miofibril asap cair selama penyimpanan suhu ruang dan suhu kulkas, menghitung total koliform dan $E$. coli pada sosis tidak dicoating selama penyimpanan suhu ruang dan suhu kulkas.

\section{METODOLOGI PENELITIAN}

Metode yang digunakan dalam penelitian adalah metode deskriptif yaitu menganalisa dan memberikan gambaran secermat mungkin mengenai suatu individu, keadaan, gejala, atau kelompok tertentu. Dalam hal ini mengenai total koliform dan total E. coli pada sosis ikan yang dicoating dengan miofibril asap cair, tanpa asap cair dan sosis ikan yang tidak dicoating dan disimpan pada suhu ruang $28-29^{\circ} \mathrm{C}$, dan suhu kulkas $10-13^{\circ} \mathrm{C}$. Pengujian yang dilakukan dalam penelitian ini meliputi analisa total koliform dan E. coli pada sosis ikan yang dicoating dengan mifibril asap cair, tanpa asap cair dan sosis tidak dicoating disimpan pada suhu ruang dan suhu kulkas.

\section{Alat dan Bahan}

Alat yang digunakan dalam penelitian ini yaitu autoklaf, mikroskop, timbangan, incubator, lampu spritus, alumunium foil, botol, kapas, tissue, jarum ose, kaca objek, tabung reaksi, pipet, erlenmeyer, tabung Hach, blender, cawan porselen, gelas piala.

Bahan utama yang digunakan dalam penelitian yaitu sosis ikan, edible coating dan bahan tambahan asap cair, serta media untuk uji mikrobiologi seperti EC Medium, Eosin metilene Blue Agar (EMB agar), dan media Nutrein Agar, Aquades $10 \%$, NACl $0.9 \%$, larutan buffer dan alkohol $90 \%$.

\section{Pembuatan kosentrat protein (Surimi)}

Metode pembuatan surimi yang digunakan dalam penelitian ini merupakan modifikasi dari penelitian yang dilakukan Heruwati dan Jav (1995). Cara kerjanya adalah ikan dicuci dan dibersihkan kemudian dipotong/difillet, ditimbang, Daging ikan dilumatkan (diblender), kemudian ditimbang kembali, lalu dicuci dengan air dingin pada suhu $1-5^{\circ} \mathrm{C}$ dengan volume air 5 kali volume daging lumat selama 10 menit, selanjutnya diaduk hingga homogen, Pengadukan dihentikan untuk mengendapkan daging lumat sedangkan kotoran dan lemak yang megapung di permukaan air dibuang, seterusnya daging ikan dipres dengan kain untuk memisahkan air dengan daging. Daging ikan dicuci kembali 
dengan air dingin dan ditambahkan garam sebanyak $0,3 \% \quad(\mathrm{~b} / \mathrm{v}) \quad$ serta dilakukan pengepresan kembali hingga air dihilangkan sebanyak $2 \%(\mathrm{v} / \mathrm{v})$ dan diaduk hingga homogen. Surimi yang dihasilkan disimpan dalam freezer dengan suhu $-15^{\circ} \mathrm{C}$ selama seminggu.

\section{Pembuatan edible coating dari miofibril protein ikan}

Metode pembuatan film pelapis (edible coating). Pangan yang digunakan dalam penelitian ini merupakan modifikasi dari penelitian yang telah dilakukan Santoso et al. (2007). Cara kerjanya surimi yang telah beku dicairkan (thawing) terlebih dahulu selama 30 menit, kemudian ditimbang sebanyak konsentrasi yang digunakan $6 \%(\mathrm{~b} / \mathrm{v})$ dari total keseluruhan larutan asap cair yang digunakan. Larutan asap cair $(0,8 \%)$ yang ditambahkan sebanyak $100 \mathrm{ml}$. Kemudian dipanaskan pada suhu $55^{\circ} \mathrm{C}$ selama 30 menit. Larutan ditambahkan $\mathrm{NaOH}$ hingga $\mathrm{pH}$-nya menjadi 11 , kemudian dilakukan pengadukan kemudian dipanaskan kembali pada suhu $60^{\circ} \mathrm{C}$. Kemudian ditambahkan tepung tapioka sebanyaknya $15 \%$ $(\mathrm{b} / \mathrm{v})$, serta gliserol sebanyak $1 \% \quad(\mathrm{v} / \mathrm{v})$. Suspensi dihomogenkan dan dipanaskan selama 25 menit, selanjutnya dilakukan degassing (75 Kpa, 20 menit), hasil yang didapatkan itulah larutan edible coating.

\section{HASIL DAN PEMBAHASAN}

\section{Analiasa Total Koliform}

Berdasarkan hasil analisa data total koliform sosis ikan yang disimpan pada suhu ruang $\left(28-29^{\circ} \mathrm{C}\right)$, menunjukkan bahwa sosis ikan dicoating dengan myofibril dan direndam asap cair mempunyai nilai yang paling baik, yaitu; terendah $7 \mathrm{MPN} / \mathrm{g}$ dan tertinggi 120 MPN/g. Hal ini dapat dilihat pada Gambar 1.

Dari Gambar 1 dapat dikatakan bahwa sosis ikan yang tidak dicoating mempunyai nilai paling rendah yaitu $7 \mathrm{MPN} / \mathrm{gram}$, dan nilai tertinggi $250 \mathrm{MPN} / \mathrm{g}$. Hal ini disebabkan karena komponen asap merupakan salah satu senyawa penghambat, sebagai antioksidan dan antibakteri. Asap cair adalah larutan dispersi asap dalam air, yang terbentuk dari hasil kondensasi asap pada proses pembakaran kayu dengan teknik pirolisis (Darmadji, 1996). Asap cair berwarna kecoklatan dan memiliki bau khas (Bridgwater, 2004).

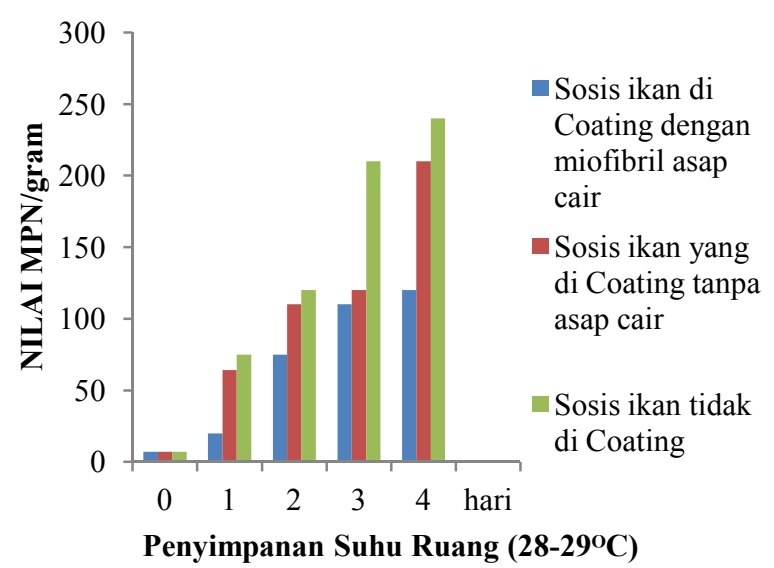

Gambar 1. Histogram total koliform pada sosis ikan yang dicoating dengan miofibril asap cair, tanpa miofibril asap cair, dan sosis ikan tidak dicoating pada suhu ruang.

Untuk suhu kulkas $\left(10-13^{\circ} \mathrm{C}\right)$, menunjukkan bahwa sosis ikan dicoating dengan miofibril dan direndam asap cair mempunyai nilai yang paling baik, yaitu nilai terendah $7 \mathrm{MPN} / \mathrm{g}$, dan tertinggi $93 \mathrm{MPN} / \mathrm{g}$ selama penyimpanan. Hal ini menunjukkan bahwa terhambatnya pertumbuhan koliform disebabkan oleh penurunan $\mathrm{pH}$ lingkungan hidupnya aktivitas senyawa antimikroba dalam asap cair dapat dilihat pada Gambar 2.

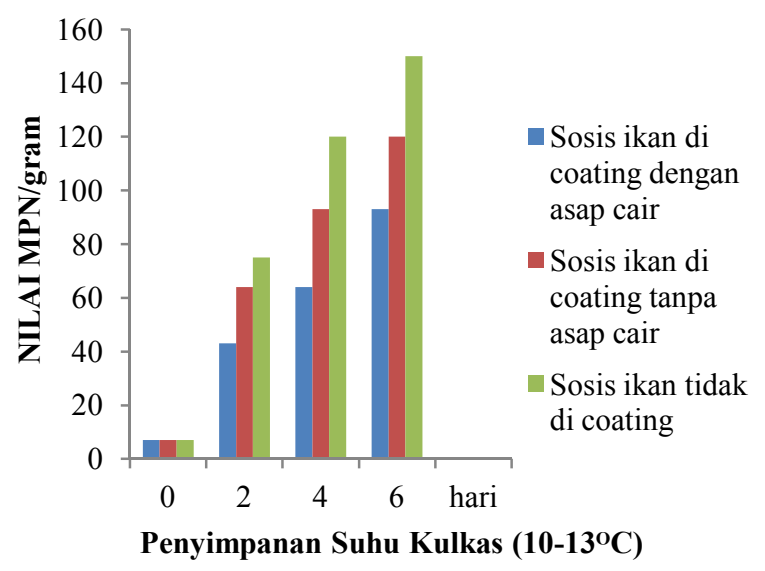

Gambar 2. Histogram total koliform pada sosis ikan yang dicoating dengan miofibril asap cair, tanpa asap cair, dan sosis ikan tidak dicoating pada suhu kulkas.

Analisis Total $E$. coli

Hasil penelitian menunjukkan bahwa total E. coli pada sosis ikan yang dicoating dengan asap cair (suhu ruang, $28-29^{\circ} \mathrm{C}$ ), dengan nilai terendah yaitu $3 \mathrm{MPN} / \mathrm{g}$. Suhu kulkas sebesar $<3 \mathrm{MPN} / \mathrm{g}$. Sosis ikan yang dicoating tanpa asap cair pada suhu ruang 
dengan nilai tertinggi $4 \mathrm{MPN} / \mathrm{g}$ dan suhu kulkas sebesar $3 \mathrm{MPN} / \mathrm{g}$, sosis ikan tidak dicoating pada suhu ruang dengan nilai tertinggi yaitu sebesar $5 \mathrm{MPN} / \mathrm{g}$, dan suhu kulkas sebesar 4 MPN/g. Berdasarkan nilai tersebut sosis ikan tidak dicoating memiliki nilai total mikroba tertinggi dari sosis ikan yang dicoating dengan asap cair dan sosis ikan yang dicoating tanpa asap cair. Hal ini kemungkinan disebabkan karena sosis yang dibeli di swalayan Jumbo sudah mengandung $E$. coli.

E. coli merupakan salah satu bakteri patogen dan biasanya bakteri ini dapat digunakan sebagai indikator dari pengolahan makanan yang tidak higienis, sehingga mampu menghasilkan enterotoksin yang dapat langsung dideteksi dalam makanan. Daging merupakan jenis makanan yang banyak ditumbuhi bakteri ini. Toksin yang dihasilkan oleh E. coli akan sulit dihilangkan walaupun makanan yang tercemar toksin tersebut disimpan di dalam lemari es dan umumnya toksin tersebut tahan terhadap pemanasan yang digunakan pada pemasakan (Palupi, dkk., 2010). Untuk lebih jelas dapat dilihat pada Gambar 3 dan 4.

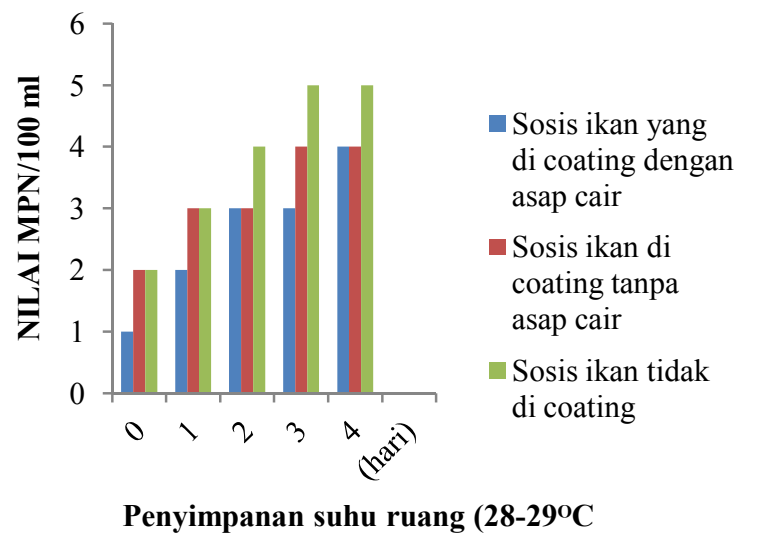

Gambar 3. Histogram total E. coli pada sosis yang dicoating dengan asap cair, tanpa asap cair dan sosis tidak dicoating disimpan pada suhu ruang.

Berdasarkan hasil analisa total E. coli menunjukkan bahwa sosis ikan yang dicoating dengan asap cair disimpan pada suhu kulkas yang paling baik dengan nilai terendah yaitu $<3$ $\mathrm{MPN} / \mathrm{g}$. Hal ini disebabkan karena pengaruh pencampuran asap cair. Asap cair juga mempunyai beberapa keunggulan yaitu memiliki aktivitas antibakteri dan antioksidan (Muratore $d k k, 2007$ ).

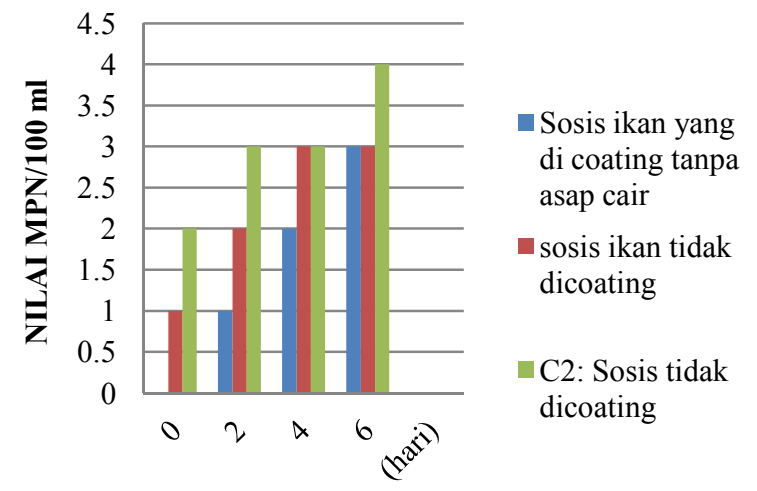

Penyimpanan suhu kulkas $\left(10-\mathbf{1 3}^{\circ} \mathrm{C}\right)$

Gambar 4. Histogram total E. coli pada sosis ikan yang dicoating dengan asap cair, tanpa asap cair, dan sosis tidak dicoating disimpan pada suhu kulkas.

Hasil penelitian pada Gambar 4 menyatakan bahwa sosis ikan tidak dicoating mempunyai nilai yang paling tinggi yaitu 4 MPN/g pada suhu kulkas. Hal ini merupakan suatu pertanda praktek sanitasi yang kurang baik. Menurut Sayler et al., (1994) menyatakan bahwa faktor-faktor yang mempengaruhi keberadaan bakteri ini adalah temperatur, $\mathrm{pH}$, sanitasi, peralatan dan pekerja.

\section{KESIMPULAN}

Hasil analisis data total koliform pada suhu kulkas menunjukkan bahwa sosis ikan yang dicoating dengan asap cair jumlahnya lebih sedikit bila dibandingkan dengan suhu ruang dan total $E$. coli menunjukkan bahwa sosis ikan yang dicoating dengan asap cair jumlahnya paling sedikit.

Total koliform pada suhu kulkas menunjukkan bahwa sosis ikan yang dicoating tanpa asap cair jumlahnya lebih sedikit, bila dibandingkan dengan suhu ruang.

Total koliform pada suhu ruang menunjukkan bahwa sosis ikan tidak dicoating lebih banyak dibandingkan dengan suhu kulkas dan total E. coli menunjukkan bahwa sosis ikan tidak dicoating jumlahnya lebih banyak.

\section{DAFTAR PUSTAKA}

Aswar. 1995. Pengolahan Fish nugget dari Ikan Nila Merah. Skripsi. Jurnal Pengolahan Hasil Perikanan, Fakultas Perikanan IPB. Bogor

Buckle, K.A, R.A, Edwards, G.H, Fleet dan M, Wooton, 1987. Ilmu pangan. UIP, Jakarta 
Girrard J. P. 1992. Smoking. In : Technology of Meat and Meat Products, Girard JP. and Morton I. (Ed). Ellis Horwood Limited, New York.

Heruwati, E. S. dan Jav, T. (1995). Pengaruh Jenis Ikan Dan Zat Penambah Terhadap Elastisitas Surimi Ikan Air Tawar. Jurnal Perikanan Indonesia (1): 16.

Hadiwitoyo, S. Teknologi Pengolahan Hasil Perikanan. Liberty. Yogyakarta

Krochta, J. M., E. A. Baldwin, dan M. O. NisperosCarriedo. 1994. Edible Coating and Film to Improve food Quality. Technomic Publ. Co. Inc. Pennsylvania, USA.
Robertson L. 1995. Pemanfaatan Limbah Beberapa Industri Perikanan Untuk Pembuatan Petis. Fakultas Perikanan. Universitas Sam Ratulangi.

Sayles, A. A. and D. D. Whit, 1994. Bacterial Pathogenesis A Molecular Approach. ASM. Press. Washington, D.C.

Santoso, Priyanto G. Purnomo. 2007. Pemanfaatan Buah Kolang-Kaling Sebagai Active Edible Film Sebagai Pengemas Primer Lempok Durian. Jurnal Bisnis Agribisnis dan Industrial Pertanian PPS. UNSRIT. 